MONIKA BOROWIEC

Uniwersytet Pedagogiczny w Krakowie

\title{
Zmiany kierunków kształcenia akademickiego w Polsce
}

W procesie kształtowania gospodarki opartej na wiedzy i przezwyciężania skutków kryzysu gospodarczego coraz większego znaczenia nabierają zasoby intelektualne, które zależą od funkcjonowania szkolnictwa, zwłaszcza na poziomie wyższym. W procesie podnoszenia jakości zasobów intelektualnych istotny jest nie tylko poziom wykształcenia społeczeństwa, ale i kierunek ukończonych studiów, który determinuje możliwości efektywnego funkcjonowania na rynku pracy.

W niniejszych rozważaniach zmierzano do określenia zmian funkcjonowania szkolnictwa wyższego w Polsce i przemian struktury kształcenia akademickiego w latach 1990 2008, ze szczególnym uwzględnieniem zmian w ostatnich latach na tle Unii Europejskiej. Szkolnictwo wyższe w Europie podlega przemianom, które wiążą się ściśle z realizacją idei budowania Europejskiego Obszaru Szkolnictwa Wyższego jako najważniejszego założenia Procesu Bolońskiego. Głębokie reformy strukturalne związane z jego realizacją polegają m.in. na gruntownej przebudowie systemów zapewniania jakości i akredytacji, zmianie koncepcji kształcenia (reorientacja na efekty), zmianie w mechanizmach zarządzania i finansowania (Morawski 2009).

Proces Boloński obejmuje różne obszary działań, które generalnie zmierzają do pewnego ujednolicenia struktury edukacji, propagowania kształcenia ustawicznego oraz zwiększenia mobilności studentów i pracowników, co stwarza szanse na podnoszenie kwalifikacji, wzrost konkurencyjności uczelni, rozwój nowych kierunków kształcenia, upowszechnienie nauczania języków obcych oraz upowszechnienie umiejętności wykorzystywania mediów elektronicznych - zwłaszcza Internetu (Borowiec 2010a). W działania te wpisuje się również idea kształtowania Europejskiego Obszaru Badawczego, który ma na celu wzrost konkurencyjności nauki i badań europejskich, likwidację barier we współpracy naukowej, szybszą realizację prac badawczych i ewentualnego wdrożenia wyników badań, a także uświadamianie roli nauki i edukacji w życiu współczesnego społeczeństwa i procesach rozwoju gospodarczego.

\section{ZRÓŻNICOWANIE STRUKTURY KIERUNKÓW KSZTAŁCENIA AKADEMICKIEGO W EUROPIE}

W 2009 r. w Unii Europejskiej funkcjonowało ok. 4 tys. instytucji szkolnictwa wyższego i kształciło się $19 \mathrm{mln}$ studentów, tj. 17\% uczących się na wszystkich poziomach edukacji. 
Udział studentów w ogólnej liczbie kształcących się osób w poszczególnych państwach Europy waha się od 29,9\% w Grecji do 2,9\% w Luksemburgu (ryc. 1). Wysokim udziałem studentów (powyżej 20\%) odznaczają się również Słowenia, Łotwa, Litwa, Polska, Finlandia i Estonia. Natomiast najniższy udział studentów (poniżej 14\%) zaznaczył się w Liechtensteinie, na Malcie, Cyprze, w Niemczech i w Turcji.

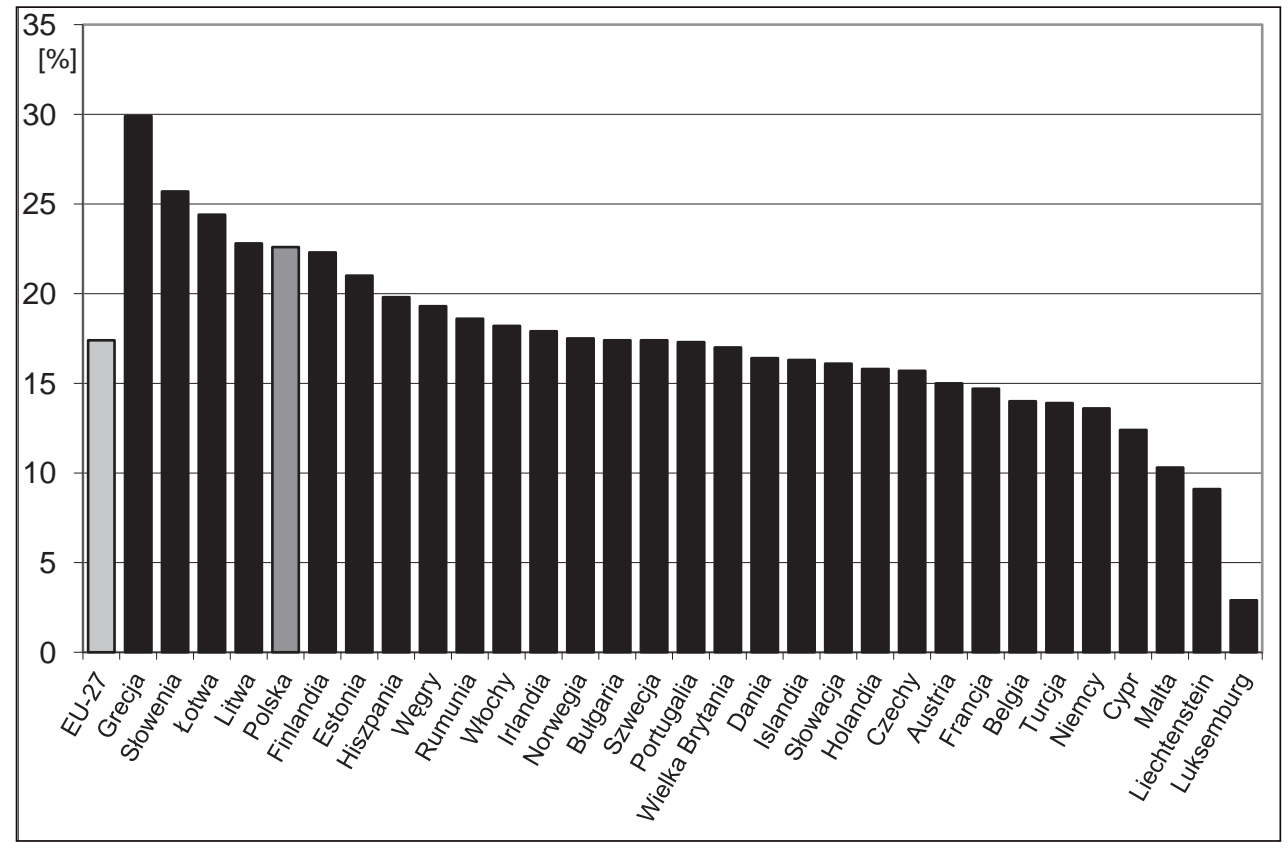

Ryc. 1. Zróżnicowanie udziału studentów (ISCED 5 i 6) w ogólnej liczbie uczniów i studentów w poszczególnych państwach Europy w 2006 r.

Źródło: opracowanie własne na podstawie Kluczowe dane o edukacji w Europie 2009, Komisja Europejska

Zainteresowanie młodzieży kierunkami kształcenia w poszczególnych państwach jest zróżnicowane, podobnie jak systemy edukacji, oferta kierunków studiów, jakość kształcenia czy zapotrzebowanie na rynku pracy.

W 2006 r. w Unii Europejskiej dominowali absolwenci nauk społecznych, ekonomii i prawa, którzy stanowili aż 36,4\% ogólnej liczby absolwentów. Kolejne pozycje zajmowali absolwenci zdrowia i nauk społecznych (13,5\%), a następnie edukacji $(13,2 \%)$, inżynierii, produkcji i budownictwa (11,8\%), humanistyki i sztuki (10,2\%). Łącznie absolwenci tych pięciu grup kierunków stanowili 74,9\% ogólnej liczby absolwentów. Mniejsze znaczenie w strukturze kierunków mieli absolwenci edukacji, nauk ścisłych, matematyki, informatyki, usług oraz rolnictwa i weterynarii, którzy łącznie stanowili 25,1\% ogólnej liczby absolwentów.

Udział absolwentów kierunków z grupy zdrowie i opieka społeczna w ogólnej liczbie absolwentów w poszczególnych państwach w Europie wahał się od 24,6\% w Norwegii i w Szwecji do 5,2\% na Łotwie, absolwentów kierunków z grupy inżynieria, produkcja i budownictwo od 20,7\% w Finlandii do 1,6\% w Bułgarii, absolwentów kierunków z grupy humanistyka i sztuka od 19,1\% w Irlandii do 5,1\% w Słowenii, absolwentów kierunków z grupy edukacja od $26,5 \%$ na Islandii do $2,1 \%$ we Francji, absolwentów kierunków z grupy 
usługi od 14,3\% na Cyprze do 0,8\% w Wielkiej Brytanii, absolwentów kierunków z grupy rolnictwo i weterynaria od $4,0 \% \mathrm{w}$ Turcji do $0,2 \%$ na Cyprze (tab. 1).

Tab. 1. Zróżnicowanie udziału absolwentów poszczególnych kierunków studiów w państwach Europy w 2006 r.

\begin{tabular}{|c|c|c|c|c|c|c|c|c|}
\hline Państwa & 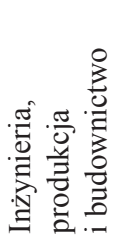 & 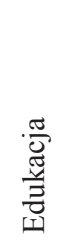 & 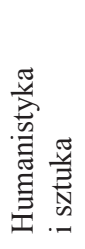 & 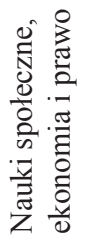 & 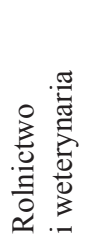 & 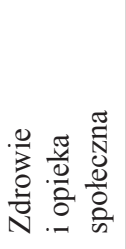 & 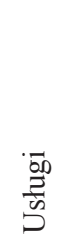 & 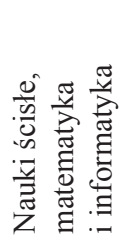 \\
\hline EU-27 & 12,5 & 10,1 & 12,2 & 35,4 & 1,7 & 14,4 & 3,9 & 9,9 \\
\hline Finlandia & 20,7 & 6,5 & 13,5 & 23,4 & 2,3 & 19,1 & 6,0 & 8,7 \\
\hline Austria & 19,7 & 13,9 & 8,7 & 29,6 & 2,1 & 9,9 & 3,7 & 12,5 \\
\hline Szwecja & 17,9 & 16,5 & 6,0 & 24,1 & 1,0 & 24,6 & 2,1 & 7,9 \\
\hline Hiszpania & 16,5 & 12,3 & 9,2 & 28,3 & 1,8 & 14,3 & 7,6 & 10,1 \\
\hline Rumunia & 16,2 & 2,8 & 12,2 & 49,4 & 2,8 & 9,9 & 2,2 & 4,6 \\
\hline Włochy & 15,9 & 4,9 & 17,0 & 38,7 & 1,7 & 12,4 & 2,6 & 6,8 \\
\hline Litwa & 15,9 & 16,4 & 6,7 & 40,9 & 1,8 & 9,0 & 3,5 & 5,9 \\
\hline Czechy & 15,7 & 15,4 & 7,9 & 30,2 & 3,8 & 13,1 & 5,9 & 8,0 \\
\hline Słowacja & 15,0 & 16,1 & 6,3 & 27,4 & 2,9 & 17,1 & 6,7 & 8,6 \\
\hline Francja & 14,7 & 2,1 & 12,1 & 41,6 & 1,5 & 13,0 & 3,9 & 11,1 \\
\hline Turcja & 14,4 & 17,4 & 6,5 & 37,9 & 4,0 & 5,7 & 6,3 & 7,8 \\
\hline Niemcy & 13,6 & 9,6 & 16,0 & 23,9 & 1,9 & 20,5 & 3,2 & 11,5 \\
\hline Portugalia & 12,9 & 12,9 & 8,8 & 27,4 & 1,6 & 20,6 & 6,2 & 9,7 \\
\hline Słowenia & 12,7 & 9,2 & 5,1 & 49,4 & 2,4 & 9,9 & 7,7 & 3,5 \\
\hline Irlandia & 12,1 & 6,3 & 19,1 & 34,8 & 0,6 & 11,0 & 2,4 & 13,8 \\
\hline Dania & 10,9 & 8,4 & 13,8 & 30,4 & 2,1 & 23,8 & 3,3 & 7,2 \\
\hline Estonia & 9,9 & 10,2 & 11,5 & 36,6 & 2,2 & 11,6 & 8,6 & 9,4 \\
\hline Belgia & 9,8 & 18,0 & 10,2 & 29,6 & 2,4 & 19,8 & 2,2 & 8,0 \\
\hline $\begin{array}{l}\text { Wielka } \\
\text { Brytania }\end{array}$ & 8,4 & 11,2 & 15,7 & 31,0 & 0,9 & 18,6 & 0,8 & 13,6 \\
\hline Polska & 8,4 & 17,3 & 8,7 & 42,6 & 1,7 & 7,8 & 5,0 & 8,5 \\
\hline Holandia & 8,3 & 15,9 & 8,2 & 38,3 & 1,5 & 16,5 & 4,5 & 6,8 \\
\hline Norwegia & 7,5 & 17,9 & 8,8 & 27,1 & 1,1 & 24,6 & 4,8 & 8,2 \\
\hline Lotwa & 6,8 & 15,2 & 6,2 & 56,1 & 1,0 & 5,2 & 4,9 & 4,6 \\
\hline Węgry & 6,5 & 18,1 & 7,4 & 42,7 & 2,6 & 8,6 & 8,5 & 5,6 \\
\hline Islandia & 6,4 & 26,5 & 11,2 & 34,1 & 0,7 & 11,7 & 1,4 & 8,0 \\
\hline Malta & 4,8 & 12,1 & 15,5 & 44,2 & 1,0 & 13,0 & 3,1 & 6,3 \\
\hline Cypr & 4,2 & 11,2 & 10,0 & 43,7 & 0,2 & 6,7 & 14,3 & 9,7 \\
\hline Bułgaria & 1,6 & 6,9 & 8,4 & 47,9 & 2,1 & 6,2 & 7,7 & 5,3 \\
\hline
\end{tabular}


Największym zróżnicowaniem, na co wskazuje wysoka wartość współczynnika zmienności, odznaczały się kierunki z grupy usługi $(75,6 \%)$, a najniższym kierunki z grupy nauki społeczne, ekonomia, prawo $(25,8 \%)$ oraz nauki ścisłe: matematyka i informatyka $(28,1 \%)$. Zróżnicowanie udziału absolwentów pozostałych grup kierunków w państwach Europy było na średnim poziomie.

Jak wspomniano, najwięcej młodzieży kończyło kierunki z grupy nauki społeczne, ekonomia i prawo, ale udział absolwentów tego kierunku w poszczególnych państwach wahał się od 56,1\% na Łotwie do 23,4\% w Finlandii (ryc. 2).

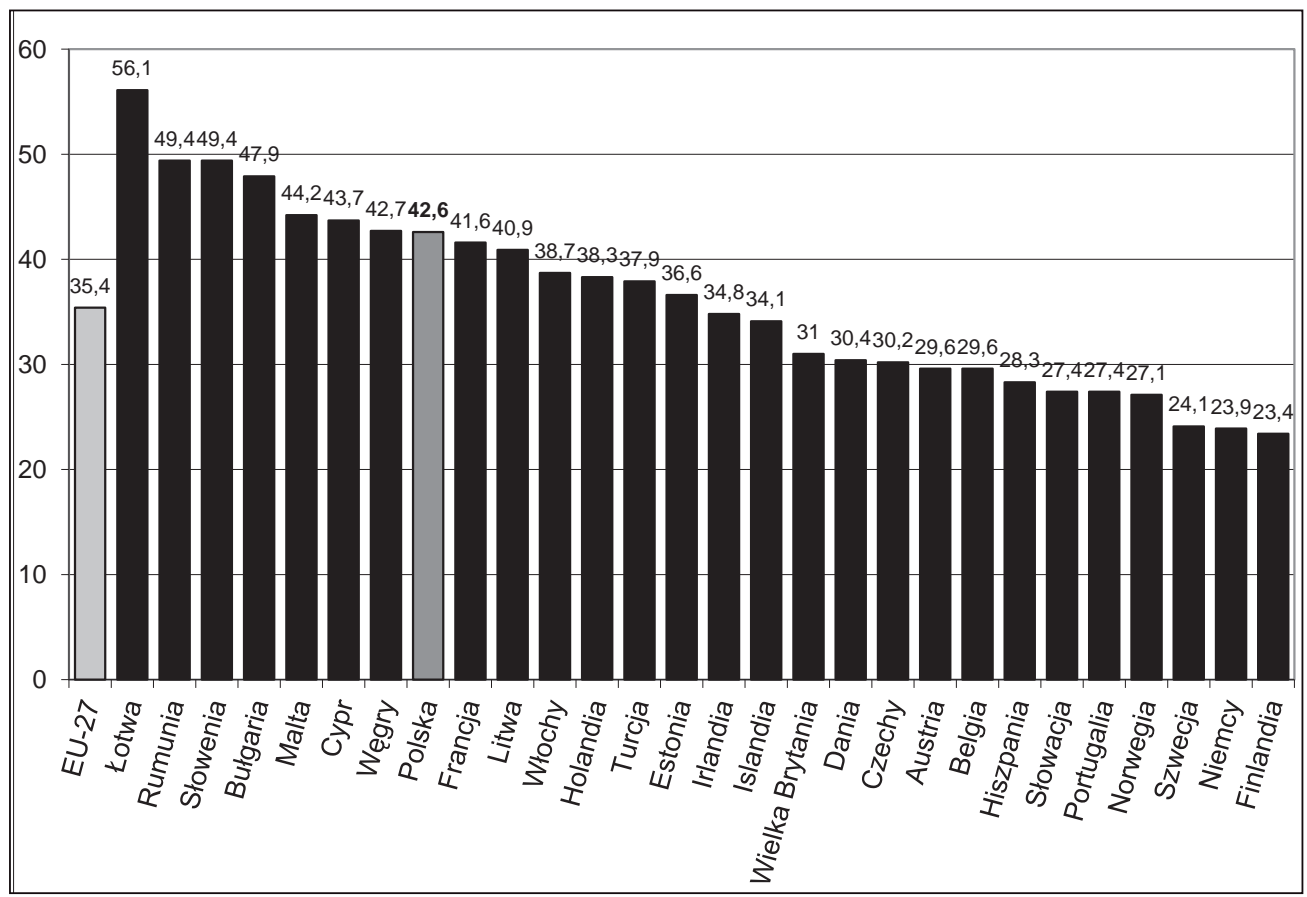

Ryc. 2. Zróżnicowanie udziału absolwentów kierunków z grupy nauki społeczne, ekonomia i prawo w państwach Europy w 2006 r.

Źródło: opracowanie własne na podstawie tab. 1

Szczególne znacznie dla kształtowania gospodarki opartej na wiedzy mają absolwenci kierunków nauk ścisłych, matematyki i informatyki, ich udział utrzymuje się na poziomie ok. 8\% absolwentów (ryc. 3). Najwyższy udział absolwentów nauk ścisłych, matematyki i informatyki w ogólnej liczbie absolwentów był w Irlandii $(13,8 \%)$, Wielkiej Brytanii (13,6\%), Austrii (12,5\%), Niemczech (11,5\%) oraz Hiszpanii $(10,1 \%)$, a najniższy w Słowenii (3,5\%), w Rumunii i na Łotwie (4,6\%), w Bułgarii (5,3\%), na Węgrzech (5,6\%). W Polsce był on na poziomie średniego europejskiego i wynosił 8,5\%.

W 2006 r. w strukturze absolwentów w Polsce, podobnie jak w UE, dominowali absolwenci nauk społecznych, ekonomii i prawa, ale ich udział wynoszący aż 42,6\% znacznie przewyższał średni europejski. Natomiast drugą pozycję zajmowali absolwenci edukacji, którzy stanowili aż 17,3\% (o 7,2 p.p. więcej niż średnio w UE). Kolejne pozycje zajmowali absolwenci trzech grup kierunków o zbliżonym udziale: humanistyki i sztuki $(8,7 \%)$, nauk 
ścisłych, matematyki i informatyki $(8,5 \%)$ oraz inżynierii, produkcji i budownictwa $(8,4 \%)$. Łącznie absolwenci tych pięciu grup kierunków studiów stanowili 85,5\% ogólnej liczby absolwentów szkół wyższych w Polsce.

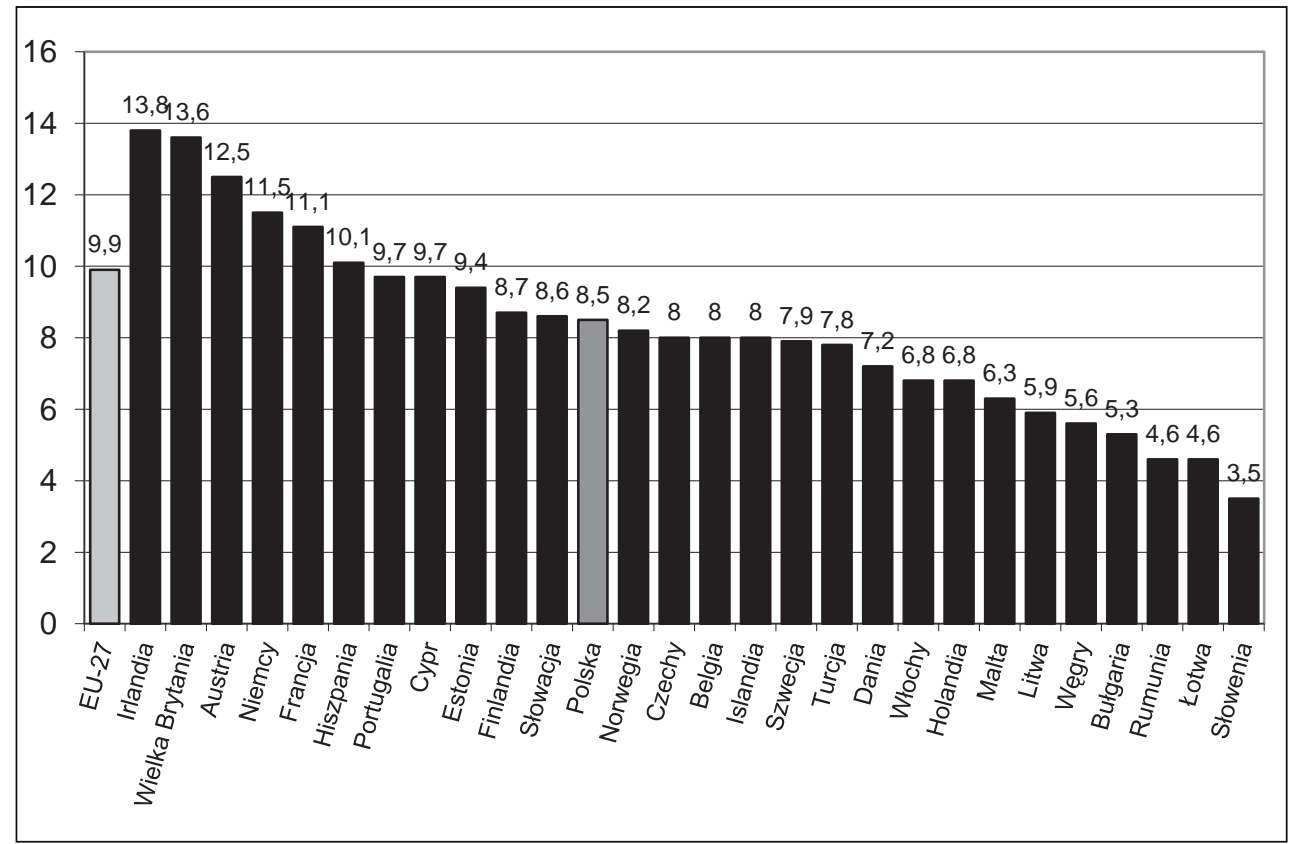

Ryc. 3. Zróżnicowanie udziału absolwentów kierunków z grupy nauki ścisłe, matematyka i informatyka w państwach Europy w 2006 r.

Źródło: opracowanie własne na podstawie Kluczowe dane o edukacji w Europie 2009, Komisja Europejska

Mniejszy udział w ogólnej liczbie absolwentów w porównaniu do średniego europejskiego stanowili absolwenci zdrowia i opieki społecznej (o 6,8 p.p.), inżynierii, produkcji i budownictwa (o 4,1 p.p.) oraz humanistyki i sztuki (o 3,5 p.p.).

\section{ZRÓŻNICOWANIE WYDATKÓW}

NA DZIAŁALNOŚĆ BADAWCZO-ROZWOJOWĄ W PAŃSTWACH UE

Powszechnie przyjmuje się, że czynnikiem decydującym o kierunkach i poziomie rozwoju społeczno-ekonomicznego jest jakość funkcjonowania systemu nauki i szkolnictwa oraz przestrzenne oddziaływanie ośrodków akademickich, które wpływa na jakość zasobów intelektualnych społeczeństwa w układach lokalnych i regionalnych. Współcześnie szkoły wyższe, podlegające (jak wspomniano) wielu przemianom związanym m.in. z procesami internacjonalizacji, muszą dostosować swoją ofertę, by przygotować dla gospodarki, nauki, oświaty i kultury pracowników o nastawieniu innowacyjnym oraz kadry specjalistów nowych zawodów lub przeobrażających się specjalności. 
W celu sprostania tym nowym wyzwaniom stojącym przed szkolnictwem wyższym i w konsekwencji przyśpieszenia wzrostu konkurencyjności gospodarki poprzez zwiększanie potencjału i jakości zasobów intelektualnych konieczne jest zwiększenie wydatków na działalność badawczo-rozwojową i szkolnictwo wyższe. Jednakże pomimo przyjętych założeń strategii lizbońskiej, mającej właśnie na celu zwiększenie konkurencyjności europejskiej gospodarki, m.in. poprzez wzrost wydatków na działalność badawczo-rozwojową w państwach Unii Europejskiej do 3\% PKB, cel ten został osiągnięty tylko w Szwecji $(3,6 \%)$ i Finlandii $(3,5 \%)$ (ryc. 4$)$.

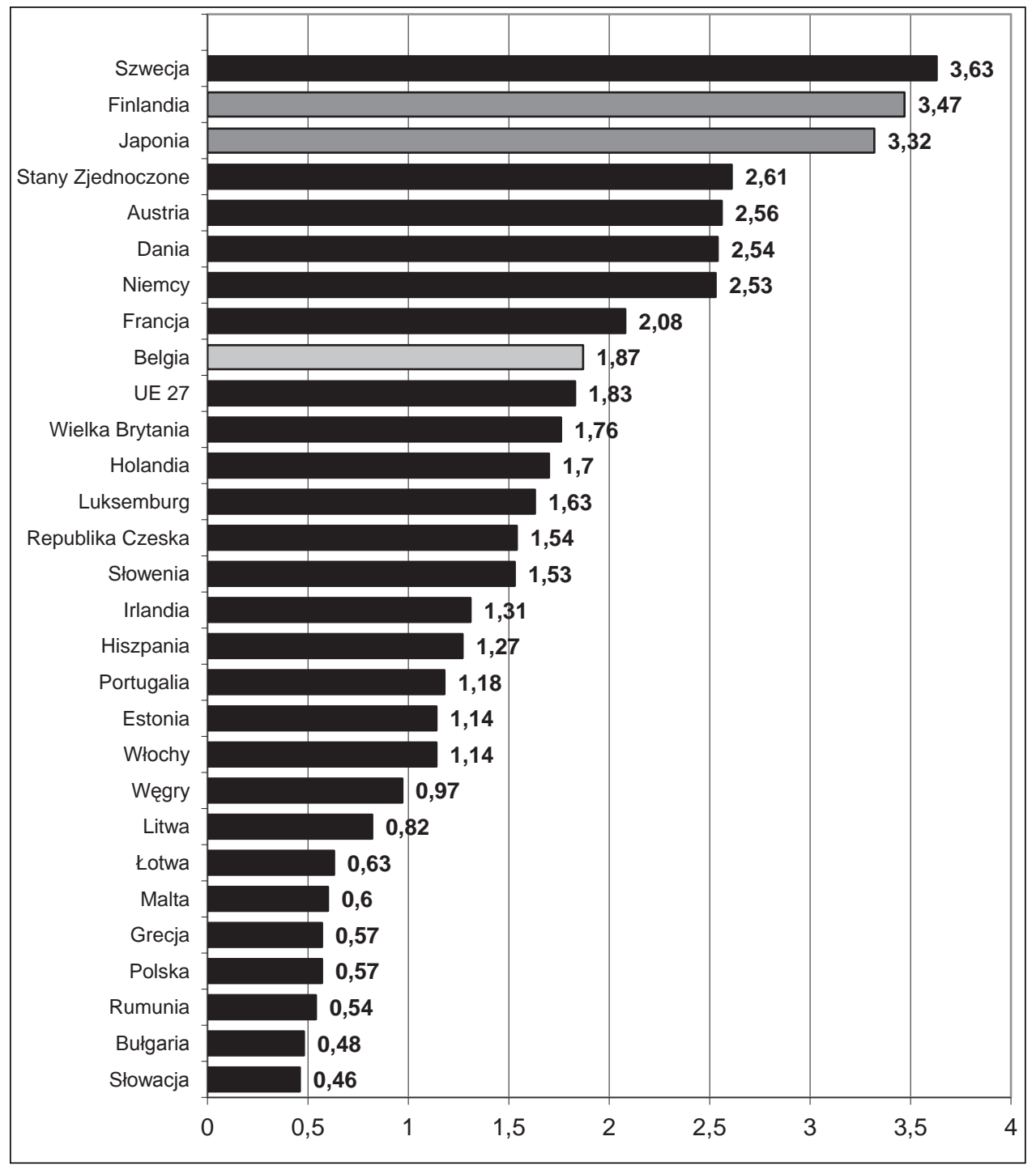

Ryc. 4. Zróżnicowanie udziału wydatków na działalność badawczo-rozwojową w PKB w 2007 r.

Źródło: opracowanie własne na podstawie: Rozmus A., Cyran K., Finansowanie działalności badawczo-rozwojowej w Polsce i innych krajach - diagnoza i próba oceny, Kwartalnik „e-Finanse”, WSIiZ, Rzeszów 2010 
Średni poziom tych wydatków w Unii Europejskiej wynosi tylko 1,9\% i w niewielu państwach, poza wspomnianą Szwecją i Finlandią, poziom ten jest wyższy. Państwami tymi są Austria, Dania, Niemcy, Francja, Belgia. Najmniejszymi wartościami tego wskaźnika (poniżej 0,6\% PKB) odznaczają się Cypr, Słowacja, Bułgaria, Rumunia, Polska i Grecja.

W Polsce ten bardzo niski poziom finansowania nauki i szkolnictwa wyższego staje się hamulcem rozwoju gospodarki opartej na wiedzy. Przyjęto, że osiągnięcie wskaźników finansowania nauki i szkolnictwa wyższego na poziomie 2\% PKB w 2013 r. pozwoliłoby w pewnym stopniu nadrobić zaniedbania w tej dziedzinie. Osiagnięcie tego celu oznaczałoby, że wydatki publiczne na szkolnictwo wyższe przez następne lata powinny wzrastać w tempie ok. $6 \%$ rocznie. Wydatki publiczne na naukę, wynoszące zaledwie ok. $0,34 \%$ PKB ( $0,55 \%$ PKB łącznie publiczne i prywatne), musiałyby wzrastać w tempie ok. 33\% rocznie, aby osiagnąc w tym okresie 1\% PKB. Jak pisze J. Wilkin (2009, s. 116),,[...] sprawy rozwoju nauki i szkolnictwa wyższego mają niski priorytet w decyzjach władz politycznych [...], wbrew powszechnym oczekiwaniom, potrzebom i deklaracjom politycznym w Polsce spada udział wydatków publicznych na szkolnictwo wyższe w PKB”.

\section{Przemiany SZKolnictwa Wyższego w Polsce}

W LATACH TRANSFORMACJI GOSPODARKI

W latach transformacji gospodarki narodowej polskie szkolnictwo wyższe podlegało wielu przemianom ilościowym i jakościowym, wśród których do najważniejszych należą: znaczny wzrost liczby studentów, rozwój niepublicznego szkolnictwa wyższego, powstawanie nowych ośrodków akademickich, rozwój studiów niestacjonarnych oraz przemiany struktury kierunków kształcenia (m.in. Chojnicki, Czyż 2000, Kruszewski 2000, Szulc 2004, Buchner-Jeziorska 2005, Bajerski 2009, Borowiec 2010b).

W latach 1990-2010 liczba studentów w Polsce zwiększyła się z 403,8 tys. do 1,9 mln, tj. 470,5\%, a liczba uczelni ze 112 do 467, tj. do 417,0\%. Na wzmożony pęd edukacyjny w tym okresie wskazuje także znaczny wzrost współczynnika skolaryzacji brutto z 12,9\% do $53,7 \%$ i współczynnika skolaryzacji netto z 9,8\% do 40,9\%.

Szczególnie wysoki wzrost liczby studentów zaznaczył się w uczelniach niepublicznych z 3,0 tys. w 1991 r. do 633,1 tys. w 2009 r., tj. ponad 21-krotny, natomiast w uczelniach publicznych liczba studentów zwiększyła się z 403,8 tys. do 1,3 mln, tj. do 313,8\% (ryc. 5). W konsekwencji nastąpiły zmiany w strukturze kształcenia przejawiające się wzrostem udziału studentów uczelni niepublicznych w ogólnej liczbie studentów z $0,7 \%$ do $33,3 \%$.

W latach przechodzenia z gospodarki centralnie sterowanej do gospodarki rynkowej nastapił znaczny wzrost zapotrzebowania na wysokowykwalifikowane kadry i specjalistów nowych zawodów, co spowodowało wyraźne przemiany struktury kierunków kształcenia akademickiego.

W 1990 r. największa liczba studentów (69,4 tys.) studiowała na kierunkach z grupy technicznej i stanowili oni 17,2\% ogólnej liczby studentów (Bajerski 2009). Kolejne pozycje zajmowali studenci kierunków pedagogicznych (14,2\%), humanistycznych $(13,8 \%)$ oraz ekonomicznych i administracyjnych (13,2\%) (ryc. 6). 


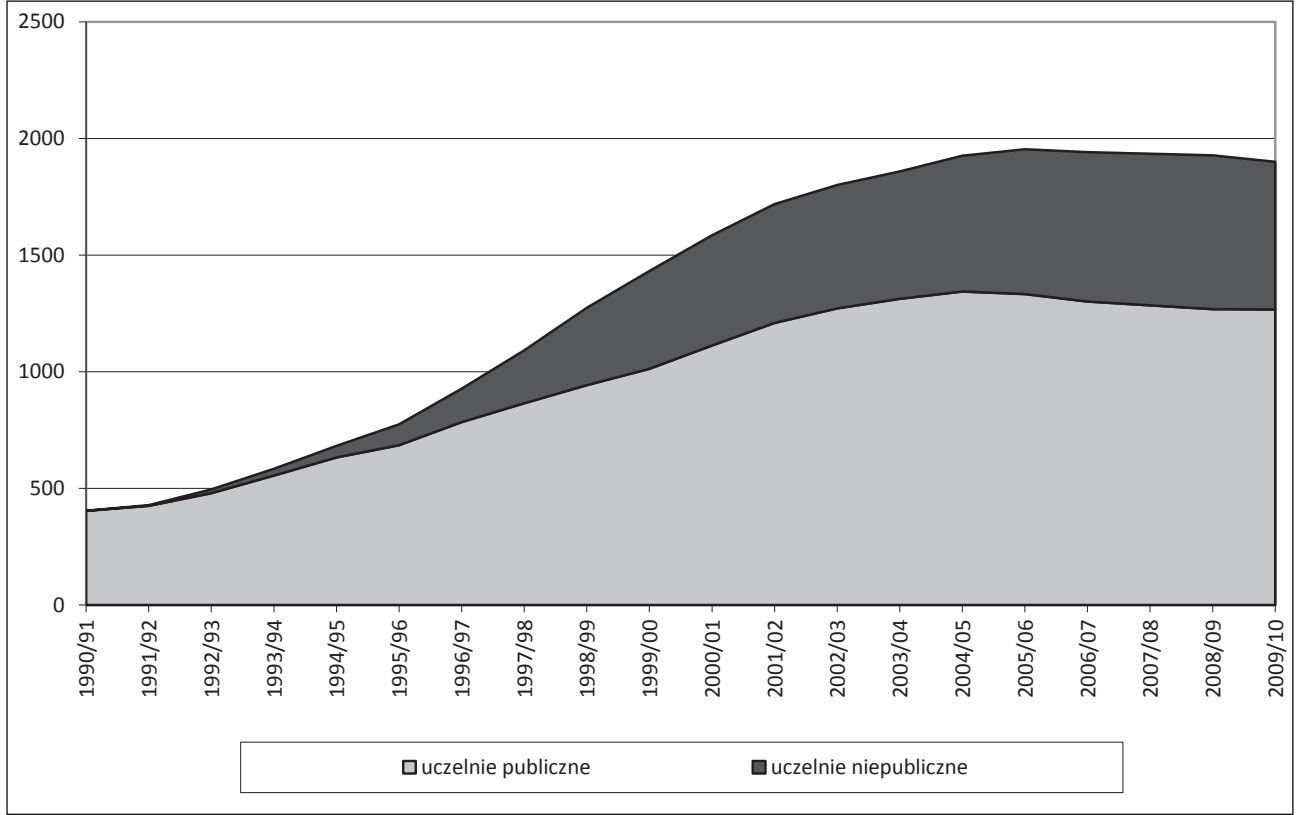

Ryc. 5. Zmiany liczby studentów w uczelniach publicznych i niepublicznych w latach 1990-2010 w Polsce

Źródło: opracowanie własne na podstawie: Bajerski 2009

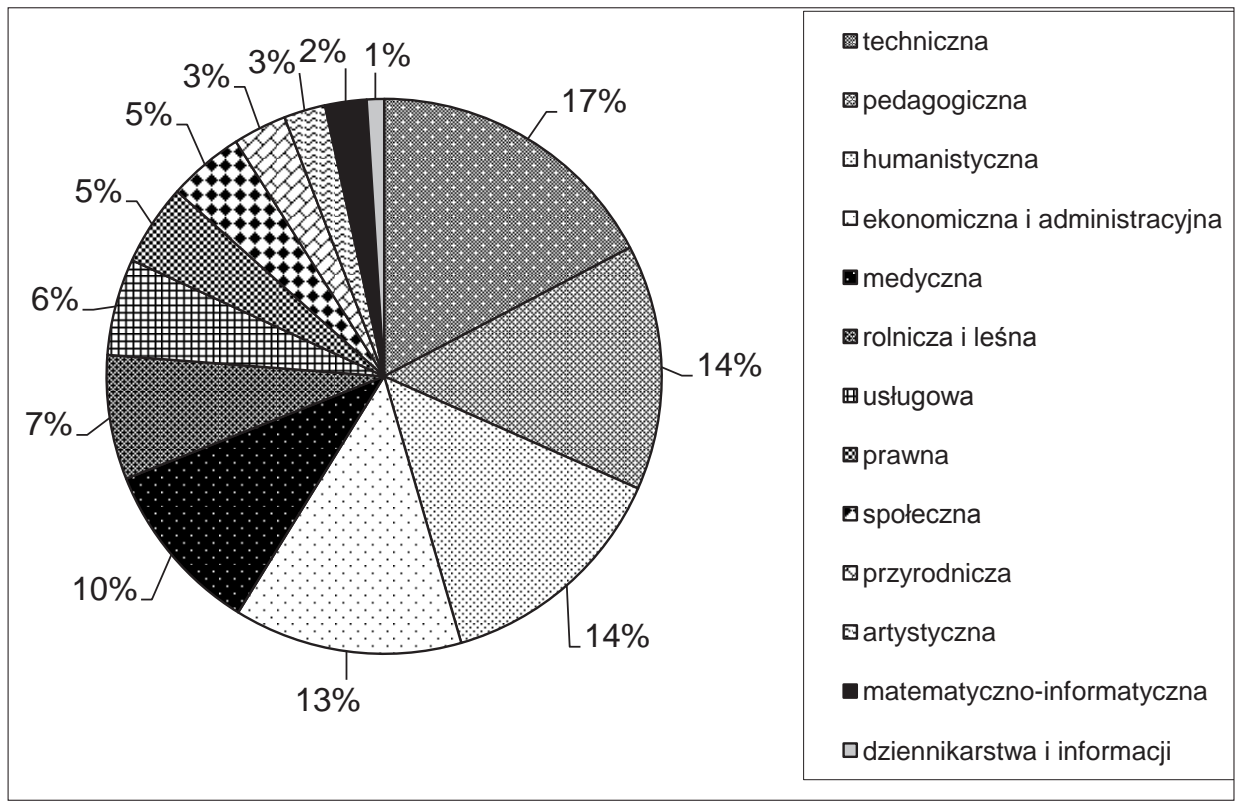

Ryc. 6. Struktura kształcenia studentów według grup kierunków studiów w 1990 r. w Polsce Źródło: opracowanie własne na podstawie: Bajerski 2009 
W latach 1990-2006 nastąpiły wyraźne zmiany w zakresie zainteresowania kierunkami studiów przejawiające się znacznym zwiększeniem liczby studentów na kierunkach z grupy społecznej z 17,6 tys. do 280,9 tys. (tj. czternastokrotnym wzroście) i ich udziału w strukturze kierunków kształcenia akademickiego z 4,4\% do 14,5\%, tj. 10,1 p.p. (ryc. 7).

W latach tych zaznaczył się również znaczny wzrost liczby studentów na kierunkach matematyczno-informatycznych z 9,7 tys. do 117,8 tys. (tj. jedenastokrotny) ale ich udział w strukturze kierunków kształcenia wciąż pozostaje nieduży (zwiększył się z 2,4\% w 1990 r. do $6,1 \%$ w 2006 r., tj. o 3,7 p.p.).

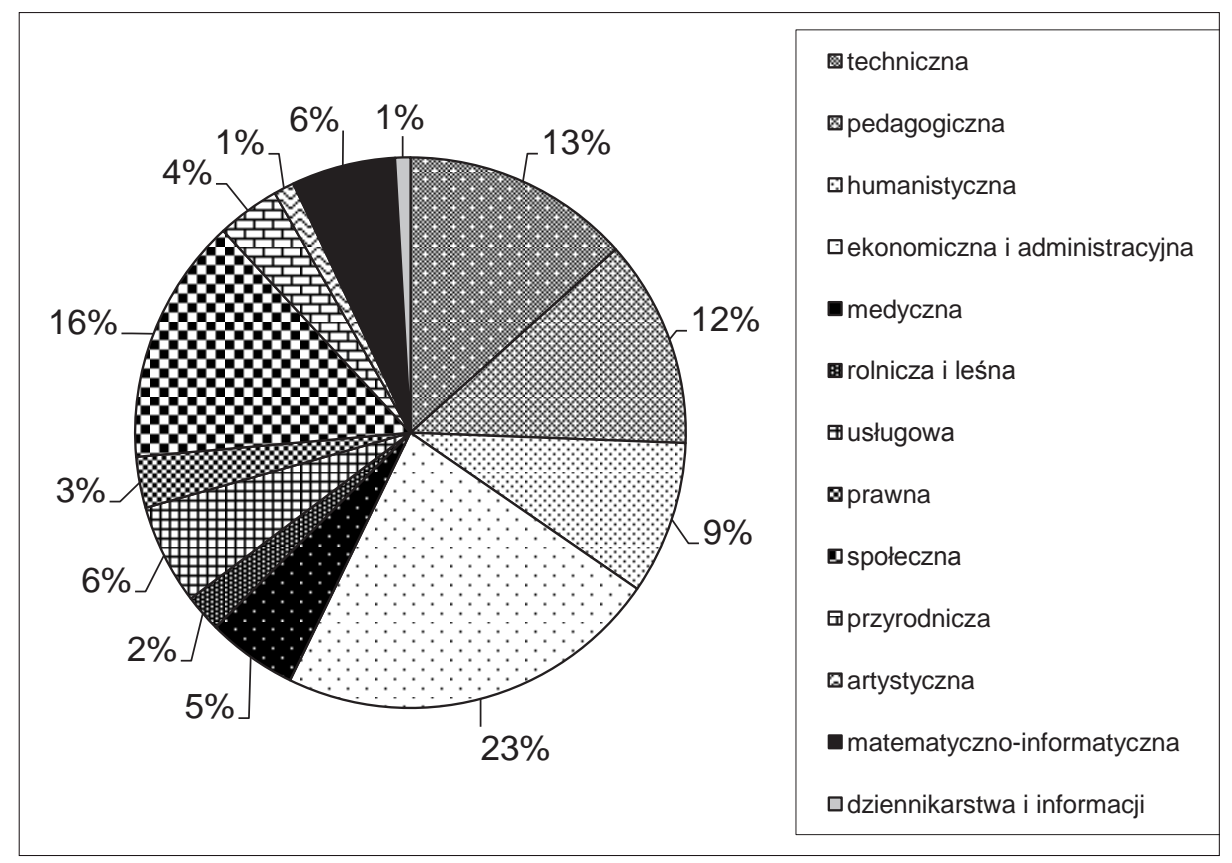

Ryc. 7. Struktura kształcenia studentów według grup kierunków studiów w 2006 r. w Polsce

Źródło: opracowanie własne na podstawie: Bajerski 2009

W okresie tym obserwuje się także wzrost zainteresowania kierunkami ekonomicznymi i administracyjnymi, liczba studentów tych kierunków zwiększyła się z 53,5 tys. do 437,8 tys., tj. ponad ośmiokrotnie, a udział studentów tych kierunków zwiększył się z 13,2\% do $22,6 \%$, tj. o 9,4 p.p.

Natomiast w badanych latach nastapił spadek udziału studentów kierunków podgrupy rolniczej i leśnej z 7,2\% do 2,2\%, tj. o 5,0 p.p., humanistycznej z 13,8\% do 9,0\%, tj. 4,8 p.p., medycznej z 10,1\% do 5,3\%, tj. o 4,8 p.p. oraz technicznej z 17,2\% do 13,4\%, tj. o 3,8 p.p.

Porównując strukturę kształcenia na uczelniach publicznych i niepublicznych w $2008 \mathrm{r}$., okazuje się, że w uczelniach niepublicznych udział studentów nauk społecznych, gospodarki i prawa był znacznie wyższy niż na publicznych (o 22 p.p.). Wyższym udziałem studentów w uczelniach niepublicznych niż w uczelniach publicznych odznaczały się tylko kierunki z grupy kształcenie i usługi. 
Natomiast na uczelniach niepublicznych udział studentów z grupy technika, przemysł i budownictwo był aż o 17 p.p. niższy niż w publicznych i stanowili oni zaledwie 2,5\% ogólnej liczby studentów na tego typu uczelniach.

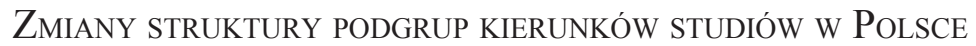

Analizując szczegółowo zmiany struktury kształcenia akademickiego (według podgrup kierunków studiów), okazuje się, że w 2004 r. największy udział w strukturze kształcenia mieli studenci podgrupy ekonomicznej i administracyjnej (21,8\%), następnie społecznej (niemal 13\%) i pedagogicznej (10,9\%) (ryc. 8).

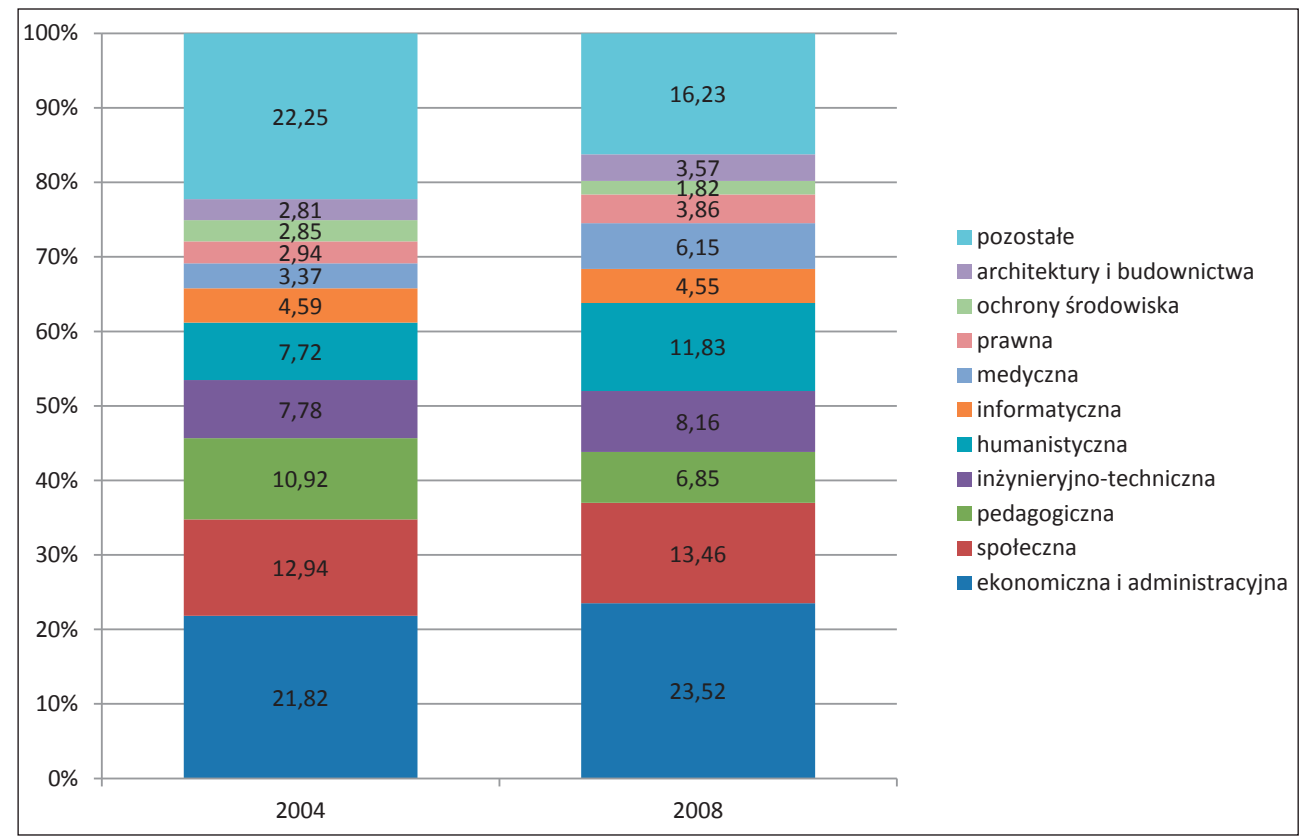

Ryc. 8. Zmiany struktury kształcenia studentów według podgrup kierunków studiów w 2004 r. i 2008 r. w Polsce

Źródło: opracowanie własne na podstawie: Szkoły wyższe i ich finanse w 2004 r. i 2008 r., Informacje i opracowania statystyczne, GUS, 2005, 2009, Warszawa

W uczelniach publicznych i niepublicznych struktura podgrup kierunków kształcenia była odmienna (ryc. 9). W szkołach niepublicznych udział studentów podgrupy ekonomicznej i administracyjnej wynosił aż 31,6\% i przewyższał o 14 p.p. ich udział w uczelniach publicznych. Kolejną pozycję w strukturze kształcenia akademickiego w uczelniach niepublicznych zajmowali studenci podgrupy społecznej, którzy stanowili 17,3\% ogólnej liczby studentów. Udział studentów podgrupy społecznej w uczelniach niepublicznych przewyższał o 6,3 p.p. ich udział w uczelniach publicznych. 
Natomiast w szkołach publicznych druga pozycję w strukturze kształcenia zajmowali studenci podgrupy inżynieryjno-technicznej, których udział wynosił 11,2\% ogólnej liczby studentów, podczas gdy w uczelniach niepublicznych studenci tych kierunków stanowili zaledwie $0,1 \%$. Podobnie w uczelniach publicznych wyższym udziałem niż w niepublicznych odznaczali się studenci podgrupy humanistycznej (o 5,4 p.p.) i medycznej (o 3,6 p.p.).

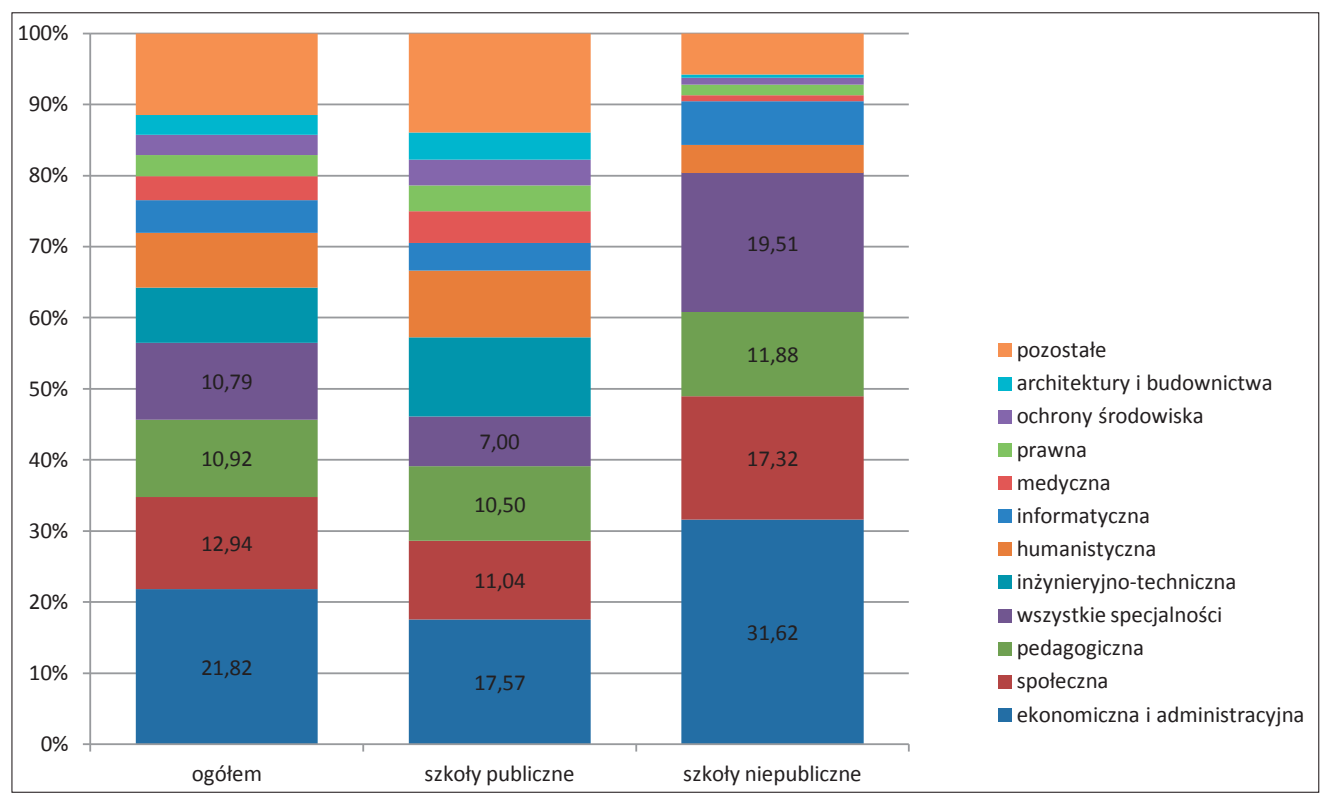

Ryc. 9. Struktura kształcenia według podgrup kierunków studiów

w szkołach publicznych i niepublicznych w 2004 r. w Polsce

Źródło: opracowanie własne na podstawie: Szkoly wyższe i ich finanse w $2004 \mathrm{r}$. Informacje i opracowania statystyczne, GUS, 2005, Warszawa

W 2008 r. nie nastąpiły zasadnicze zmiany w strukturze kształcenia. W porównaniu do 2004 r. zaznaczył się nieznaczny wzrost udziału studentów kierunków humanistycznych (o 4,1 p.p.), ekonomicznych i administracyjnych (o 1,7 p.p.) oraz medycznych (o 2,8 p.p.) w ogólnej liczbie studentów (ryc. 14). Zmniejszył się natomiast udział studentów grupy pedagogicznej (o 4,1 p.p.) i ochrony środowiska (o 1,0 p.p.).

W 2008 r. w uczelniach publicznych największy procent stanowili studenci podgrupy ekonomicznej i administracyjnej (16,8\%), następnie społecznej $(12,2 \%)$, pedagogicznej $(10,3 \%)$, humanistycznej $(9,9 \%)$ oraz inżynieryjno-technicznej (9,5\%) (ryc. 10). Łącznie studenci tych pięciu podgrup kształcenia stanowili 58,7\% ogólnej liczby studentów uczelni publicznych.

W 2008 r. w uczelniach niepublicznych największy procent stanowili studenci podgrupy ekonomicznej i administracyjnej (36,5\%), następnie społecznej $(16,0 \%)$, humanistycznej (15,5\%), prawnej $(7,6 \%)$.

Porównując strukturę kształcenia w tych dwóch typach uczelni okazuje się, że w uczelniach niepublicznych znacznie wyższy był udział studentów podgrup: ekonomicznej i ad- 
ministracyjnej (o 19,7 p.p.), prawnej (o 5,7 p.p.), humanistycznej (o 5,6 p.p.) i społecznej (o 3,8 p.p.). Łącznie udział studentów tych czterech podgrup kształcenia akademickiego w uczelniach niepublicznych przewyższał ich udział w uczelniach publicznych o 34,8 p.p.

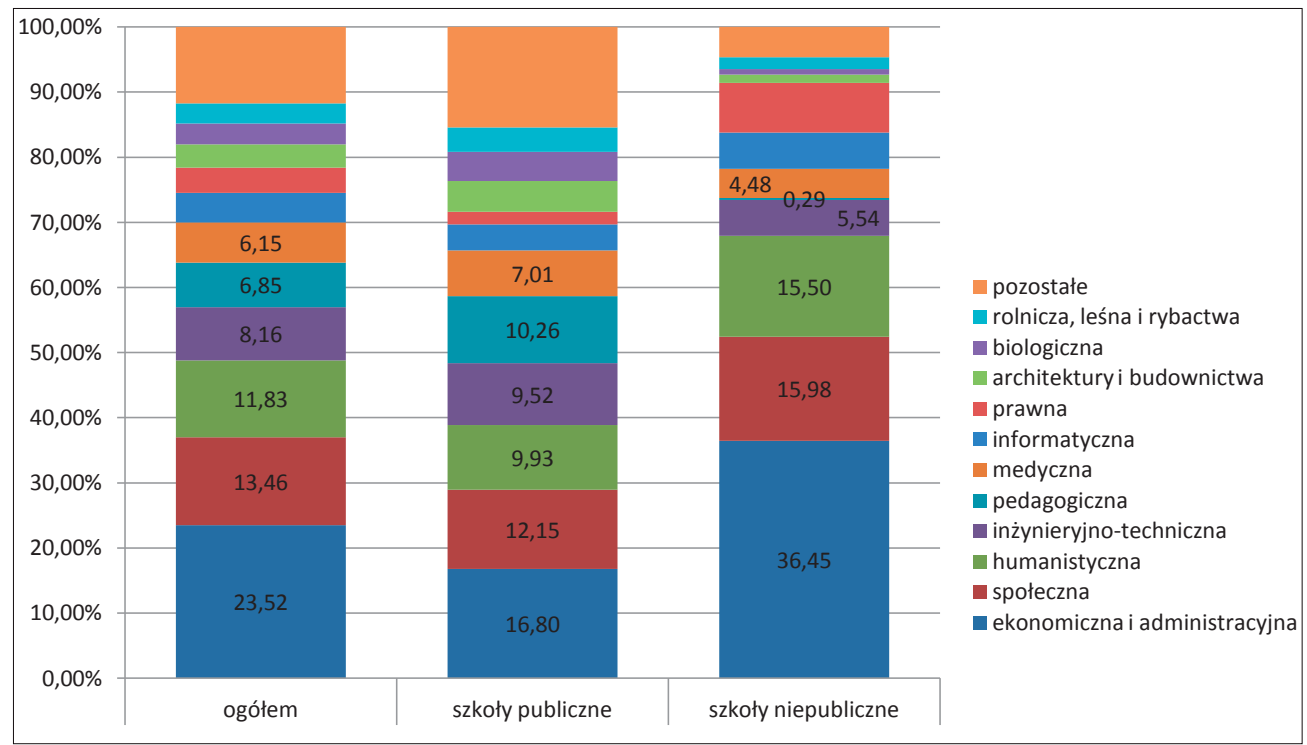

Ryc. 10. Struktura kształcenia według podgrup kierunków studiów w szkołach publicznych i niepublicznych w 2008 r. w Polsce

Źródło: opracowanie własne na podstawie: Szkoły wyższe i ich finanse w 2008 r., Informacje i opracowania statystyczne, GUS, 2009, Warszawa

W uczelniach publicznych natomiast większy procent w ogólnej liczbie studentów niż w uczelniach niepublicznych stanowili studenci podgrupy pedagogicznej (o 10,0 p.p.), inżynieryjno-technicznej (o 4,0 p.p.), biologicznej (o 3,6 p.p.), architektury i budownictwa (o 3,5 p.p.) oraz medycznej (2,5 p.p.). Łącznie udział studentów tych pięciu podgrup w uczelniach publicznych przewyższał o 23,6 p.p. ich udział w uczelniach niepublicznych.

Zmiany struktury kształcenia wynikają z możliwości kadrowych szkół i identyfikowanych oczekiwań maturzystów, a niewielkie znaczenie mają badania popytu na pracę i konsultacje z pracodawcami (Rószkiewicz 2009). Bardzo mały udział studentów kierunków inżynieryjno-technicznych w uczelniach niepublicznych wynika ze znacznej kosztochłonności tego typu studiów ze względu na konieczność zakupu aparatury badawczej i sprzętu laboratoryjnego, a zatem uczelnie tego typu kształcą głównie na kierunkach o dużej popularności.

Na podstawie danych urzędów pracy i prognozy ekonomistów, a także opinii przedsiębiorców i organizacji pracodawców, wyłoniono kierunki strategiczne dla rozwoju krajowej gospodarki i od 2008 r. Ministerstwo Nauki i Szkolnictwa Wyższego w ramach rządowego programu kierunków zamawianych dofinansowuje kształcenie studentów w dziedzinach kluczowych dla rozwoju gospodarki kraju: matematycznych, technicznych i przyrodniczych. Analizy wykazują, że osoby wykształcone w tych specjalnościach będą poszukiwane na rynku pracy, a ich kwalifikacje i wiedza staną się ważnym czynnikiem rozwoju polskiej gospodarki. 
W celu kształtowania gospodarki opartej na wiedzy poprzez zwiększanie jakości zasobów intelektualnych konieczne jest:

- zwiększenie wydatków na działalność badawczo-rozwojową i szkolnictwo wyższe,

- ciągłe dopasowywanie oferty edukacyjnej do potrzeb rynku pracy poprzez uruchamianie nowych kierunków studiów i zwiększanie praktycznych umiejętności absolwentów,

- uświadamianie znaczenia kształcenia ustawicznego, kształtowania umiejętności budowania warsztatu naukowego, współpracy i łączenia różnych obszarów wiedzy,

- rozwój kierunków ścisłych, technicznych i matematyczno-przyrodniczych,

- zmienianie programów nauczania i sposobów kształcenia w wybranych dyscyplinach na niższych poziomach kształcenia,

- podejmowanie i zacieśnianie współpracy szkół wyższych z przemysłem.

Jak przyjmuje R. Z. Morawski (2009) celem polityki gospodarczej w warunkach kryzysu finansowego powinna być stymulacja innowacyjności, kreatywności i przedsiębiorczości podmiotów odpowiedzialnych za zarządzanie szkolnictwem wyższym i wykorzystanie kryzysu jako szansy do opracowania strategii i przeprowadzenia reform polskiego szkolnictwa.

\section{Literatura}

Bajerski A., 2009, Przekształcenia struktury przestrzennej szkolnictwa wyższego po 1989 r., Bogucki Wydawnictwo Naukowe, Poznań.

Borowiec M., 2010a, Rola edukacji w procesach globalizacji, [w:] Rola przedsiębiorczości w procesach globalizacji, red. Z. Zioło, T. Rachwał, Przedsiębiorczość-Edukacja, nr 7, Zakład Przedsiębiorczości i Gospodarki Przestrzennej Instytutu Geografii Uniwersytetu Pedagogicznego w Krakowie, Wydawnictwo Nowa Era, Warszawa-Kraków, s. 13 (w druku).

Borowiec M., 2010b, Funkcjonowanie krakowskiego i rzeszowskiego ośrodka akademickiego wświetle koncepcji uktadów bipolarnych, Prace Monograficzne, nr 536, Wydawnictwo Uniwersytetu Pedagogicznego, Kraków.

Buchner-Jeziorska A. (red.), 2005, Szkoła sukcesu czy przetrwania? Szkolnictwo wyższe w Polsce, Szkoła Główna Handlowa, Warszawa.

Chojnicki Z., Czyż T., 2000, Przemiany szkolnictwa wyższego w okresie transformacji w Polsce i jego zróżnicowanie regionalne, [w:] Procesy spoleczno-gospodarcze w Polsce w końcu XX w., red. J.J. Parysek, H. Rogacki, Bogucki Wydawnictwo Naukowe, Poznań.

Kruszewski Z.P., 2000, Odbudowa wyższych uczelni niepaństwowych $w$ Polsce i ich nowe funkcje społeczno-edukacyjne, Wydawnictwo Naukowe NOVUM, Płock.

Morawski R.Z., 2009, Uwarunkowania międzynarodowe i internacjonalizacja szkolnictwa wyższego, [w:] Polskie szkolnictwo wyższe. Stan, uwarunkowania, perspektywy, Wydawnictwo Uniwersytetu Warszawskiego, Warszawa.

Rószkiewicz 2009, Diagnoza stanu szkolnictwa wyższego w Polsce. Wyzwania w obszarach strategicznych, [w:] Polskie szkolnictwo wyższe. Stan, uwarunkowania, perspektywy, Wydawnictwo Uniwersytetu Warszawskiego, Warszawa.

Szulc T., 2004, Dynamika przemian w szkolnictwie wyższym w Polsce a realizacja Procesu Bolońskiego, Nauka i Szkolnictwo Wyższe, 24 (2).

Wilkin J., 2009, Ekonomiczno-finansowe uwarunkowania rozwoju szkolnictwa wyższego w Polsce, [w:] Polskie szkolnictwo wyższe. Stan, uwarunkowania, perspektywy, Wydawnictwo Uniwersytetu Warszawskiego, Warszawa. 


\section{The changes of the structure of academic education in Poland}

The quality of intellectual resources becomes increasingly important, especially in the process of shaping the economy based on knowledge and overcoming the effects of the economic crisis. The quality of intellectual resources depends on the quality of functioning of higher education. In the process of improving the quality of intellectual resources not only the level of education of the society is essential but also the direction of graduate studies, which affects job opportunities. The aim of this article was to determine the changes in the functioning of higher education in Poland and changes of the structure of academic education in years 1990-2008, with particular emphasis on the recent years' changes. The changes were shown on the background of the European Union.

dr Monika Borowiec

Uniwersytet Pedagogiczny w Krakowie

Instytut Geografii

Zakład Przedsiębiorczości i Gospodarki Przestrzennej

e-mail: borowiec@up.krakow.pl 